\title{
Intracellular Localization of Heat Shock mRNAs (hsc70 and hsp70) to Neural Cell Bodies and Processes in the Control and Hyperthermic Rabbit Brain
}

\author{
Jane A. Foster and Ian R. Brown \\ Department of Zoology, University of Toronto, Scarborough Campus, Ontario, Canada, M1C 1A4
}

Heat shock proteins are essential cellular proteins that may play important roles in cellular repair and/or protection. This report focuses on the expression of two members of the hsp70 multigene family, namely, constitutive hsc70 mRNA and stress-inducible hsp70 mRNA in the control and hyperthermic rabbit brain. The intracellular localization of these heat shock mRNAs was examined using high-resolution nonradioactive in situ hybridization. The distribution of hsc70 mRNA and hsp70 mRNA was examined in (1) neuronal cell bodies and their dendritic processes and (2) oligodendrocytes and their cellular processes. In control animals, hsc70 mRNA was detected in the apical dendritic processes and cell bodies of cortical layer II and V neurons, CA3 and CA4 neurons, deep cerebellar neurons, and brainstem neurons. A time course analysis of hsc70 $\mathbf{~ m R A}$, after a physiologically relevant increase in body temperature of $2.6^{\circ} \mathrm{C}$, revealed more distal transport of this constitutive message into dendrites of these neuronal populations. In the same neuronal populations, basal levels of hsp70 mRNA were observed in the cell body; however, this mRNA was not detected in dendritic processes in control or hyperthermic animals. After hyperthermia, hsp70 mRNA was strongly induced in oligodendrocytes and transported to the processes of these glial cells. The localization of heat shock messages in the processes of these neural cell types could provide a mechanism for local control of synthesis of heat shock proteins in cellular compartments that are remote from the cell body.

1996 Wiley-Liss, Inc.

Key words: dendrites, in situ hybridization, stress proteins

\section{INTRODUCTION}

Heat shock proteins are highly conserved proteins found in all organisms that play roles in repair and pro- tection processes (Schlesinger et al., 1982; Lindquist, 1986; Nover and Scharf, 1991). In response to cellular stress, heat shock proteins are induced while synthesis of other cellular proteins is reduced (Ashburner and Bonner, 1979; Lindquist, 1980). Heat shock proteins have been classified into families based on their molecular weights in kilodaltons (Lindquist and Craig, 1988). The hsp70 multigene family is comprised of both constitutively expressed members and stress-inducible members (Lindquist and Craig, 1988; Welch, 1992). Constitutive hsc70s are essential cellular proteins, which function as molecular chaperones and are involved in protein folding, transport, and translocation (Gething and Sambrook, 1992; Georgopoulos and Welch, 1993; Welch, 1993; Becker and Craig, 1994; Hartl et al., 1994). Studies have suggested a repair and/or protective role for heat shock proteins that are induced after cellular stress (Pelham, 1986, 1988; Craig, 1989). Our laboratory has investigated the expression of heat shock protein genes in the central nervous system of unstressed rabbits and those following hyperthermia (reviewed by Brown, 1994). This report focuses on the intracellular distribution of constitutive hsc70 mRNA and stress-inducible hsp70 mRNA in neural cells of the rabbit brain.

Previous work in our laboratory has examined expression patterns of heat shock mRNA species at the cellular level. These studies demonstrated constitutive hsc70 mRNA expression in neurons in the rabbit cerebellum, brainstem, spinal cord, and forebrain (Manzerra and Brown, 1992a,b; Manzerra et al., 1993; Foster et al., 1995; Foster and Brown, 1996). Recent work has also revealed low basal expression of hsp $70 \mathrm{mRNA}$ in unstressed rabbit forebrain neurons (Foster and Brown, 1996). In response to a physiologically relevant in-

Received March 20, 1996; revised June 13, 1996; accepted June 18, 1996.

Address reprint requests to Ian R. Brown, Department of Zoology, University of Toronto, Scarborough Campus, 1265 Military Trail, West Hill, Ontario, Canada, MIC 1A4. 
crease in body temperature, a strong glial induction of hsp70 mRNA is observed (reviewed by Brown, 1994). In the present investigation, our previous studies have been extended to the intracellular level using nonradioactive in situ hybridization to examine the distribution of hsc 70 mRNA and hsp 70 mRNA in (1) neuronal cell bodies and their dendritic processes and (2) oligodendrocytes and their cellular processes.

There is a growing interest in the phenomenon of intracellular localization of messages to the processes of neural cells (Steward et al., 1994). Included in the list of mRNAs reported to be localized to cellular processes of neural cells are microtubule-associated protein-2 (MAP2) mRNA in dendrites (Garner et al., 1988) and myelin basic protein mRNA in processes of oligodendrocytes (Trapp et al., 1987; Landry et al., 1994). A recent study in our laboratory, which employed nonradioactive in situ hybridization, localized calmodulin I mRNA to dendritic processes of cortical neurons during postnatal development in the rat brain (Berry and Brown, 1996). Transport of mRNA into cellular processes allows for the possibility of local control of protein synthesis (Steward et al., 1994). This may provide a strategy for rapidly increasing heat shock protein levels in intracellular domains that are remote from the cell body in response to synaptic activity in unstressed cells or in response to cellular insults such as hyperthermia. The present investigation uses nonradioactive in situ hybridization to investigate whether hsc70 mRNA and hsp70 mRNA are localized to neural cell processes in the control and hyperthermic rabbit brain.

\section{MATERIALS AND METHODS}

\section{Treatment of Animals}

The body temperature of adult male New Zealand white rabbits (mean weight, $1.9 \mathrm{~kg}$ ) was elevated $2.6^{\circ} \mathrm{C}$ above normal $\left(39.6^{\circ} \mathrm{C}\right)$ by the intravenous injection of lysergic acid diethylamide (LSD) at $100 \mu \mathrm{g} / \mathrm{kg}$ as previously described (Cosgrove and Brown, 1983). We have previously shown that the induction of hsp $70 \mathrm{mRNA}$ in the rabbit brain is due to the hyperthermic effects of the drug (Manzerra and Brown, 1990). The core body temperature of the animals was monitored with a rectal thermistor probe before injection, at 15-minute intervals for 90 minutes, and at 1-hour intervals for up to 5 hours after LSD injection. Core body temperature reached maximum temperature at 1 hour and returned to normal body temperature by 4 hours. Three sets of animals were killed at $1,2,3,5$, and 10 hours post-LSD injection. Animals were anesthetized with pentobarbitol $(80 \mathrm{mg} / \mathrm{kg})$ injected via the marginal ear vein. Brains were removed, frozen in OCT embedding compound, and stored at $-70^{\circ} \mathrm{C}$ until use.

\section{Synthesis of Riboprobes}

The subclone $\mathrm{pH} 2.3$, a 2.3-kb HindIII-BamHI fragment of the human hsp70 inducible gene in pGEM1, was obtained from R. Morimoto (Northwestern University) (Wu et al., 1985). An 843-bp insert was digested out with ClaI and HindIII and subcloned into the vector pBluescript KS for preparation of hsp 70 riboprobes. Linearization with ClaI or HindIII and subsequent in vitro transcription incorporating ${ }^{35} \mathrm{~S}$ - or digoxigenin-labeled uridine triphosphate (UTP) using $\mathrm{T} 7$ and $\mathrm{T} 3$ polymerases produced antisense and sense hsp 70 riboprobes, respectively.

The subclone pHA 7.6, a 600-bp EcoRI fragment from the human constitutive hsc70 related protein $\mathrm{p} 70$ in pGEM1, was obtained from R. Morimoto (Watowich and Morimoto, 1988). The 600-bp EcoRI fragment was digested out and subcloned into the vector pBluescript $\mathrm{KS}$ for preparation of hsc70 riboprobes. Production of antisense and sense hsc70 riboprobes was achieved by linearization with HindIII or BamHI, followed by in vitro transcription incorporating ${ }^{35} \mathrm{~S}$ - or digoxigenin-labeled UTP by T7 and T3 polymerases, respectively.

We have shown that the hsp 70 riboprobe detects a $2.7-\mathrm{kb}$ mRNA in the rabbit brain and does not crosshybridize to the constitutive $2.5-\mathrm{kb}$ hsc 70 mRNA, which is detected specifically by the hsc70 riboprobe (Foster et al., 1995). No signal was apparent in tissue sections hybridized with sense hsp 70 or hsc 70 riboprobes (Foster et al., 1995).

\section{Pretreatment of Sections}

A series of $12-\mu \mathrm{m}$ frozen sections were thaw mounted on gelatin-coated glass slides ( $1 \%$ gelatin, $0.5 \%$ chromium potassium sulfate) and air dried. Tissue sections were fixed in $4 \%$ formalin (4\% formaldehyde in phosphate buffered saline) for 5 minutes, rinsed for 2 minutes in $2 \mathrm{XSSC}(0.3 \mathrm{M}$ sodium chloride, $0.03 \mathrm{M}$ sodium citrate, pH 7.0), incubated for 10 minutes in TEA $\mathrm{NaCl} / \mathrm{AA}(0.1 \mathrm{M}$ triethanolamine, $0.9 \%$ sodium chloride, $0.5 \%$ acetic anhydride) and rinsed in $2 \mathrm{XSSC}$. Slides were dehydrated in increasing ethanol concentrations, incubated in chloroform for 5 minutes to delipidate tissue, followed by 1 minute in absolute alcohol and 1 minute 95\% alcohol, and air dried (Peterson and McCrone, 1994).

\section{Nonradioactive In Situ Hybridization}

Each tissue section was hybridized overnight with $100 \mu \mathrm{l}$ of hybridization buffer containing $1 \mu \mathrm{l}$ of digoxigenin (DIG)-labeled riboprobe, $50 \%$ formamide, $10 \%$ dextran sulfate, $0.02 \%$ Ficoll, $0.02 \%$ polyvinylpyrrolidone, $0.02 \%$ bovine serum albumin (BSA), $0.5 \mathrm{mg} / \mathrm{ml}$ heparin sulfate, $0.5 \mathrm{mg} / \mathrm{ml}$ yeast tRNA, $0.4 \mathrm{mg} / \mathrm{ml} \mathrm{her-}$ 
ring testis DNA, $600 \mathrm{mM} \mathrm{NaCl}, 75 \mathrm{mM}$ sodium citrate, $\mathrm{pH} 7.0$, at $55^{\circ} \mathrm{C}$. After hybridization, slides were rinsed in Tris/ $\mathrm{NaCl}$ buffer $(500 \mathrm{mM} \mathrm{NaCl}, 1 \mathrm{mM}$ EDTA, $10 \mathrm{mM}$ Tris, $\mathrm{pH} 8.0$ ), incubated for 30 minutes in RNase buffer (500 mM NaCl, $1 \mathrm{mM}$ EDTA, $10 \mathrm{mM}$ Tris, pH 7.5) containing $20 \mu \mathrm{g} / \mathrm{ml}$ RNase $\mathrm{A}$, and washed for 1 hour at $37^{\circ} \mathrm{C}$ in RNase buffer followed by a 1 -hour wash at $70^{\circ} \mathrm{C}$ in $0.1 \mathrm{XSSC}$.

After posthybridization washes, slides were rinsed in 2XSSC and then incubated in blocking solution (2XSSC, 6\% fetal calf serum, $0.05 \%$ Triton X-100) for 1.5 hours at room temperature. After blocking, slides were incubated with anti-dioxigenin-alkaline phosphatase $(1: 1,000)$ in blocking solution for $24-36$ hours at $4^{\circ} \mathrm{C}$. Sections were washed three times for 30 minutes in Buffer $\mathrm{A}(100 \mathrm{mM}$ Tris, $\mathrm{pH} 8.0,100 \mathrm{mM} \mathrm{NaCl}), 5$ minutes in AP Buffer (100 mM Tris, pH 9.5, $100 \mathrm{mM} \mathrm{NaCl}, 50 \mathrm{mM}$ $\mathrm{MgCl}_{2}, 0.1 \%$ Tween 20), and 5 minutes in AP Buffer with $5 \mathrm{mM}$ levamisole. Slides were incubated in NBT/BCIP color reagent in AP Buffer with $5 \mathrm{mM}$ levamisole (4.5 $\mu \mathrm{l} / \mathrm{ml}$ NBT solution- $100 \mathrm{mg} / \mathrm{ml}$ 4-nitro blue tetrazolium chloride in $70 \%$ dimethylformamide; $3.5 \mu \mathrm{l} / \mathrm{ml} \mathrm{BCIP}$ solution-50 mg/ml 5-bromo-4-chloro-3-indolyl-phosphate in dimethylformamide) for 4-16 hours. Slides were rinsed in Buffer $A$ to halt the color reaction, rinsed in water, dehydrated in increasing alcohol, cleared in xylene, and mounted in $50 \%$ permount $/ 50 \%$ xylene. Data representative of 12 tissue sections are shown (4 sections per animal, three animals per treatment).

\section{RESULTS}

\section{Intracellular Distribution of hsc70 and hsp70 mRNAs in the Control Rabbit Brain}

Nonradioactive in situ hybridization with a DIGlabeled hsc70 and hsp70 riboprobes was used to examine the intracellular distribution of heat shock mRNAs in neuronal cell bodies and dendritic processes in the rabbit brain. The ability to detect mRNA in cellular processes by in situ hybridization in tissue sections is technically limited. In tissue culture systems, the cell body and the processes of individual neural cells can be visualized in their entirety. By contrast, in $12-\mu \mathrm{m}$ tissue sections that were used in the present investigation, it is not possible to trace the entire length of a process from an individual cell body because it might extend out of the plane of section. Lack of signal in neuronal and glial cell processes might reflect that the process was out of the plane of section or that signal was below detectable levels. For all results presented, 12 tissue sections from each time point were examined. In each tissue section, the intracellular localization of mRNA was examined in all hsc 70 and hsp70 mRNA-positive cells in a particular region of the tissue section. Data presented are representative of all tissue sections examined.

Expression of hsc70 mRNA was observed in neuronal-enriched regions of the rabbit forebrain, including the hippocampus and cortical layers (Fig. 1A), as previously described (Sprang and Brown, 1987; Foster and Brown, 1996). High constitutive hsc70 mRNA expression was observed in neuronal-enriched regions of the hippocampus (Figure 1D). This signal was apparent in the cell bodies of CA1 (Fig. 1B) and CA3 (Fig. 1C) neurons. At higher magnification, hsc70 mRNA was also observed in the apical dendrites of CA3 hippocampal neurons (arrowheads, Fig. 1F) but was not detected in these processes in CAl neurons (Fig. 1E). As shown in Figure 2, Hsc70 mRNA was also observed in the cell bodies and the apical dendrites of cortical neurons in layers II and V (arrowheads), whereas the signal in other cortical neurons (layers I, II, IV, VI) was confined to the cell body. Thus, in both forebrain regions of control animals, hsc70 mRNA was observed to be located in neuronal cell bodies, and additionally, in the dendritic processes of some populations of cortical and hippocampal neurons.

The cerebellum and brainstem of the control rabbit brain expressed high levels of constitutive hsc70 mRNA (Fig. 3A). Hsc70 mRNA was detected in both the cell bodies and processes of deep cerebellar neurons (Fig. 3B) and brainstem neurons (Fig. 3C), whereas in Purkinje neurons and basket cell neurons (Fig. 3D), a cell body distribution of signal was observed. At higher magnification, hsc70 mRNA was apparent in dendritic processes of deep cerebellar neurons (arrowheads, Fig. 3E) and brainstem neurons (arrowheads, Fig. 3F). This dendritic localization of hsc $70 \mathrm{mRNA}$ was most pronounced in brainstem neurons and was detected up to $25 \mu \mathrm{m}$ from the cell body (arrowheads, Fig. 3F).

Recently, we have reported basal expression of hsp 70 mRNA in cortical and hippocampal neurons of the control rabbit forebrain (Foster and Brown, 1996). Hybridization of adjacent tissue sections with hsc70 and hsp70 DIG-labeled riboprobes revealed differences in the intracellular distribution of hsc70 and hsp 70 mRNAs in control neurons (Fig. 4). The dendritic distribution of hsc70 mRNA that was apparent in cortical neurons in layer V (arrowheads, Fig. 4A) was not observed for hsp70 mRNA in this cell type (Fig. 4B). Hsc70 and hsp70 mRNA expression were detected in CA4 hippocampal neurons (Fig. 4C, D, respectively). At higher magnification, hsc70 mRNA was observed in apical dendritic processes of CA4 neurons (arrowheads, Fig. 4E), which is similar to observations shown in Figure $1 \mathrm{~F}$ for CA3 hippocampal neurons. A comparable signal was not apparent for hsp $70 \mathrm{mRNA}$ in CA4 hippocampal neurons (Fig. 4F). Therefore, although both hsc 70 and hsp70 

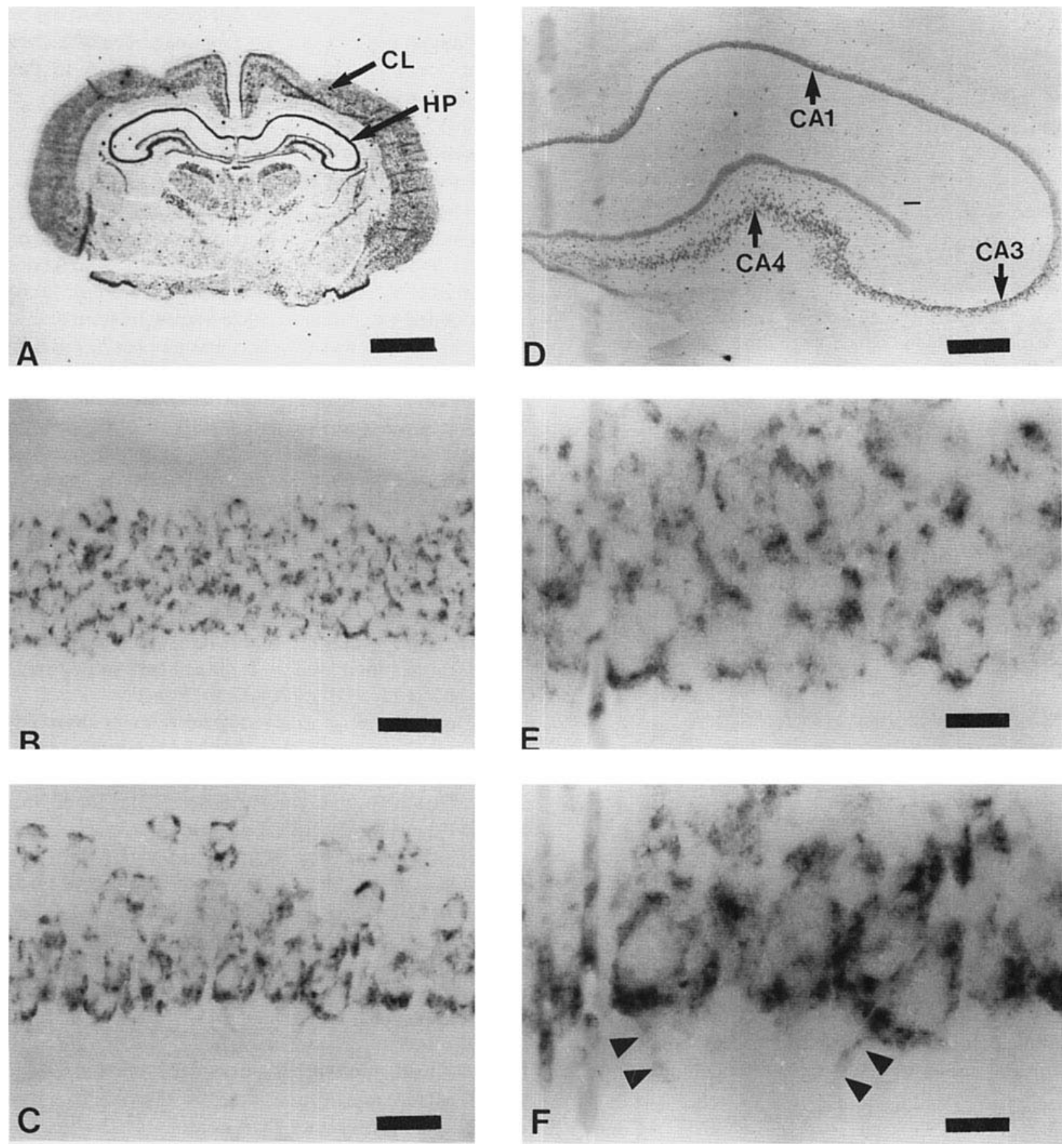

Fig. 1. Constitutive expression of hsc70 mRNA in hippocampal neurons. Constitutive expression of hsc70 mRNA was observed in neuronal-enriched regions of the rabbit forebrain including cortical layers (CL) and hippocampus (H) (A). The presence of hsc70 mRNA (black precipitate) was observed in the cell bodies of CA1 (B) and CA3 (C) neurons. D: hippo-

campus, indicating CA1, CA3, and CA4 neuronal populations. Dendritic localization of hsc 70 mRNA was observed in CA3 neurons (arrowheads, F) but not in CA1 neurons (E). Scale bars $=3.5 \mathrm{~mm}$ in $\mathrm{A} ; 37.6 \mu \mathrm{m}$ in $\mathrm{B}$ and $\mathrm{C} ; 800 \mu \mathrm{m}$ in $\mathrm{D} ; 10.6$ $\mu \mathrm{m}$ in $\mathrm{E}$ and $\mathrm{F}$. 

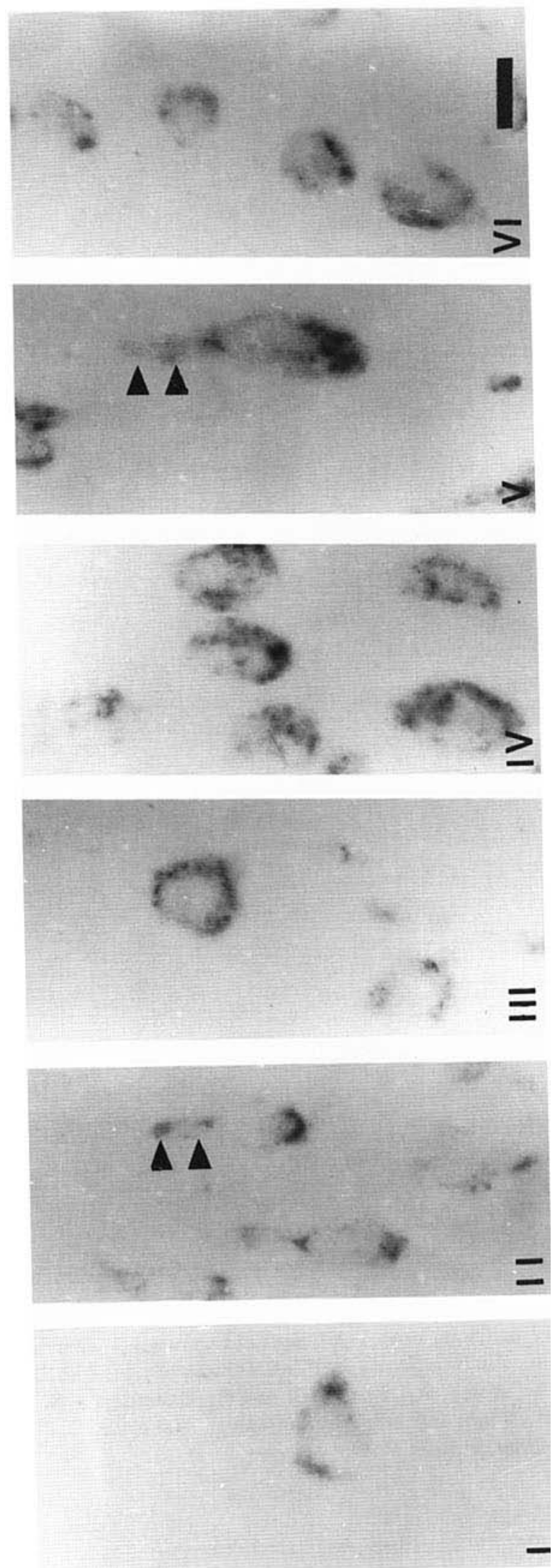

mRNAs were present in the cell bodies of cortical and hippocampal neurons in control animals, dendritic localization was observed only for hsc70 mRNA in these neuronal populations.

\section{Intracellular Distribution of Neural hsc70 and hsp70 mRNAs after Hyperthermia}

The intracellular distribution of hsc70 mRNA in hippocampal neurons at time points after physiologically relevant hyperthermia was next examined. Maximal elevation of $2.6^{\circ} \mathrm{C}$ over the normal temperature of $39.6^{\circ} \mathrm{C}$ was attained at 1 hour, with a return to normal by 4 hours. Figure 5 shows the distribution of hsc $70 \mathrm{mRNA}$ in CA4 (panels A-D) and CA3 (panels E-H) neurons after hyperthermia. More distal transport of hsc70 mRNA into dendritic processes was noted in both CA4 and CA3 neuronal populations when 1 and 3 hours are compared (Fig. 5A, C for CA4, E, G for CA3). At later time points, dendritic transport of hsc70 mRNA appeared to be reduced (Fig. 5D, CA4 neurons at 5 hours; Fig. 5H, CA3 neurons at 10 hours). As shown in Figure 6, in cortical neurons, more distal dendritic transport of hsc70 mRNA into dendritic processes was also observed after hyperthermia. Transport of hsc70 mRNA in dendritic processes was increased at 1 and 2 hours in neurons in both cortical layer II and cortical layer V.

Dendritic transport of hsc $70 \mathrm{mRNA}$ was observed in deep cerebellar neurons (Fig. 7A) and brainstem neurons (Fig. 7B) in 1-hour hyperthermic animals. Brainstem neurons, which had the highest constitutive levels of hsc70 mRNA, showed more distal dendritic transport of hsc70 mRNA at 3 hours (Fig. 7C). As shown in Figure 7D, mRNA was detectable in a long dendritic process. In this brainstem neuron, hsc70 mRNA was transported $175 \mu \mathrm{m}$ from the cell body in brainstem neurons in the 3-hour hyperthermic animal. At later time points, when body temperature had returned to normal, transport of hsc70 mRNA appeared to be reduced (Fig. 7E, 5 hours; Fig. 7F, 10 hours).

We have previously described a strong induction of hsp70 mRNA after physiologically relevant hyperthermia in glial cells rather than neurons of the forebrain (Sprang and Brown, 1987; Foster and Brown, 1996). Using combined in situ hybridization/immunocytochemistry, with glial specific markers, we have shown that oligodendrocytes and microglia but not glial fibrillary acidic protein-positive astrocytes induced hsp70 mRNA

Fig. 2. Intracellular distribution of hsc70 mRNA in control cortical neurons. Hsc70 mRNA (black precipitate) was detected in the cell body of cortical neurons of layers I-VI. In addition, layers II and $\mathrm{V}$ also showed signal in apical dendrites (arrowheads). Scale bar $=10.6 \mu \mathrm{m}$. 

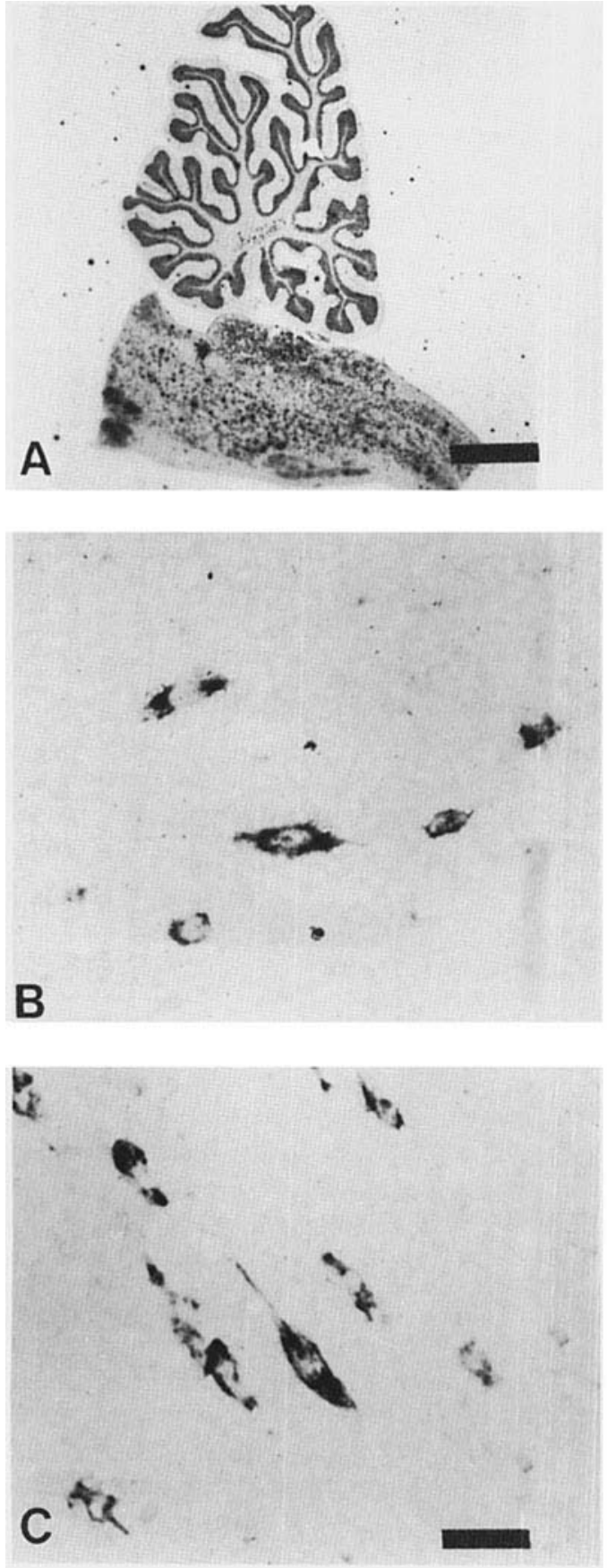

Fig. 3. Hsc70 mRNA expression in cerebellar and brainstem neurons. A: constitutive pattern of hsc $70 \mathrm{mRNA}$ expression in control cerebellum and brainstem. Hsc70 mRNA was detected in the cell bodies and processes of deep cerebellar neurons (B) and brainstem neurons $(\mathbf{C})$, whereas a cell body distribution of

(Foster and Brown, 1996). In Figure 8, the intracellular distribution of hsp70 mRNA in the cell body and processes of oligodendrocytes were examined. At 1 hour, hsp70 mRNA was localized in cytoplasmic cap regions
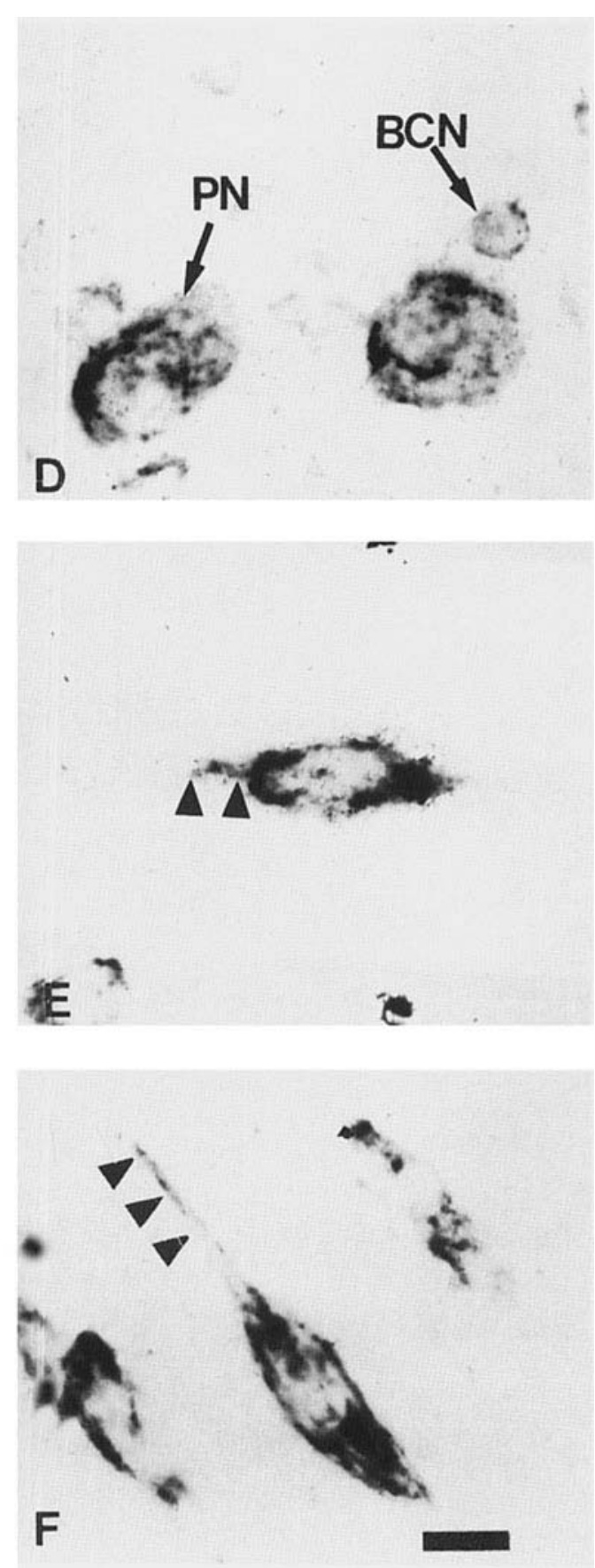

signal was observed in Purkinje neurons (PN) and basket cell neurons (BCN) (D). At higher magnification, hsc70 mRNA was detected in dendritic processes (arrowheads) of deep cerebellar neurons $(\mathbf{E})$ and brainstem neurons $(\mathbf{F})$. Scale bars $=$ $600 \mu \mathrm{m}$ in $A ; 37.6 \mu \mathrm{m}$ in $\mathrm{B}$ and $\mathrm{C} ; 10.6 \mu \mathrm{m}$ in $\mathrm{D}-\mathrm{F}$.

(see arrowheads in Fig. 8A). In 2-hour hyperthermic animals, the distribution of signal appeared more spindle-like (arrowheads, Fig. 8B), and by 3 hours it was detected more distally in processes (arrowheads, Fig. 

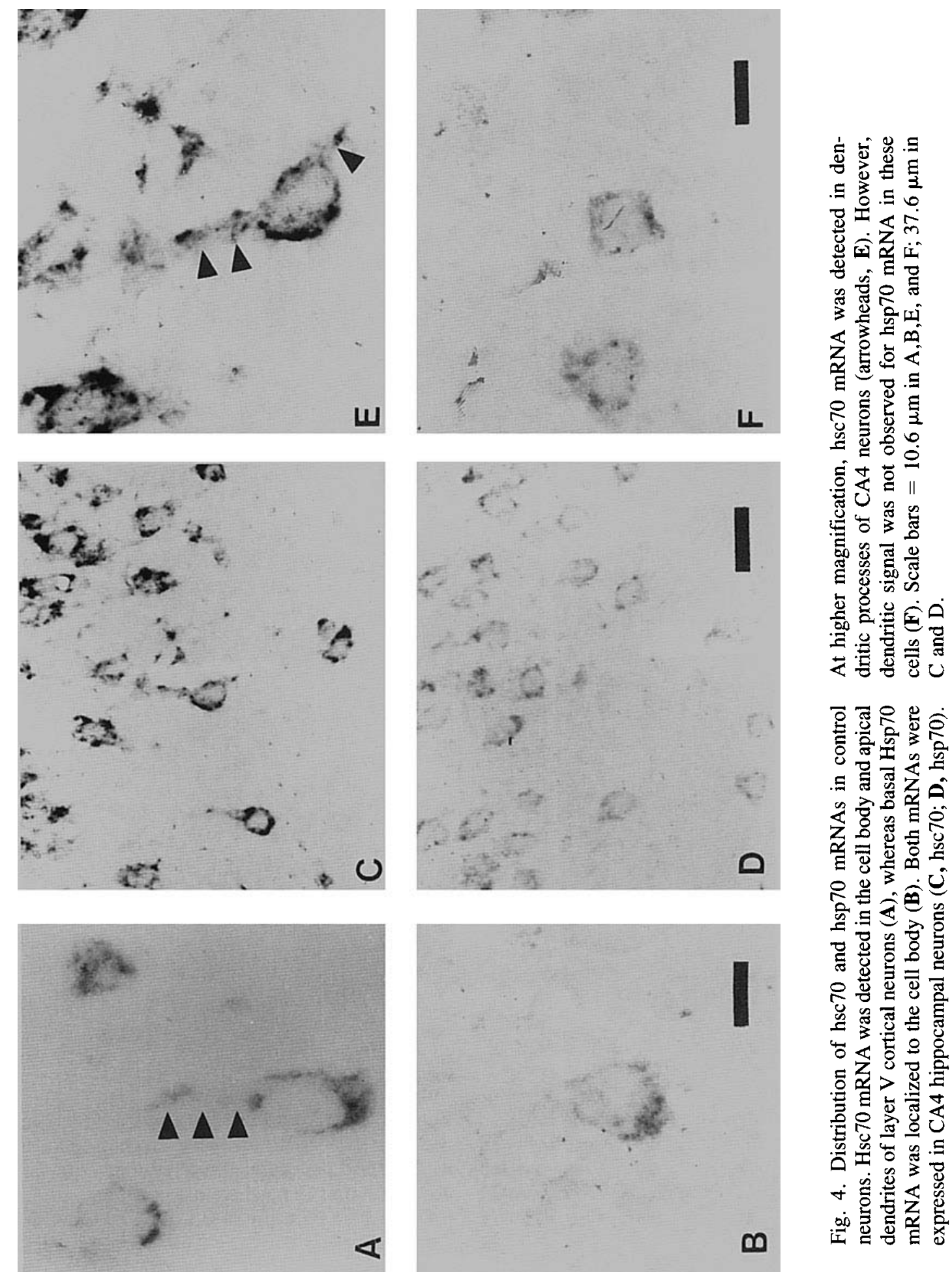

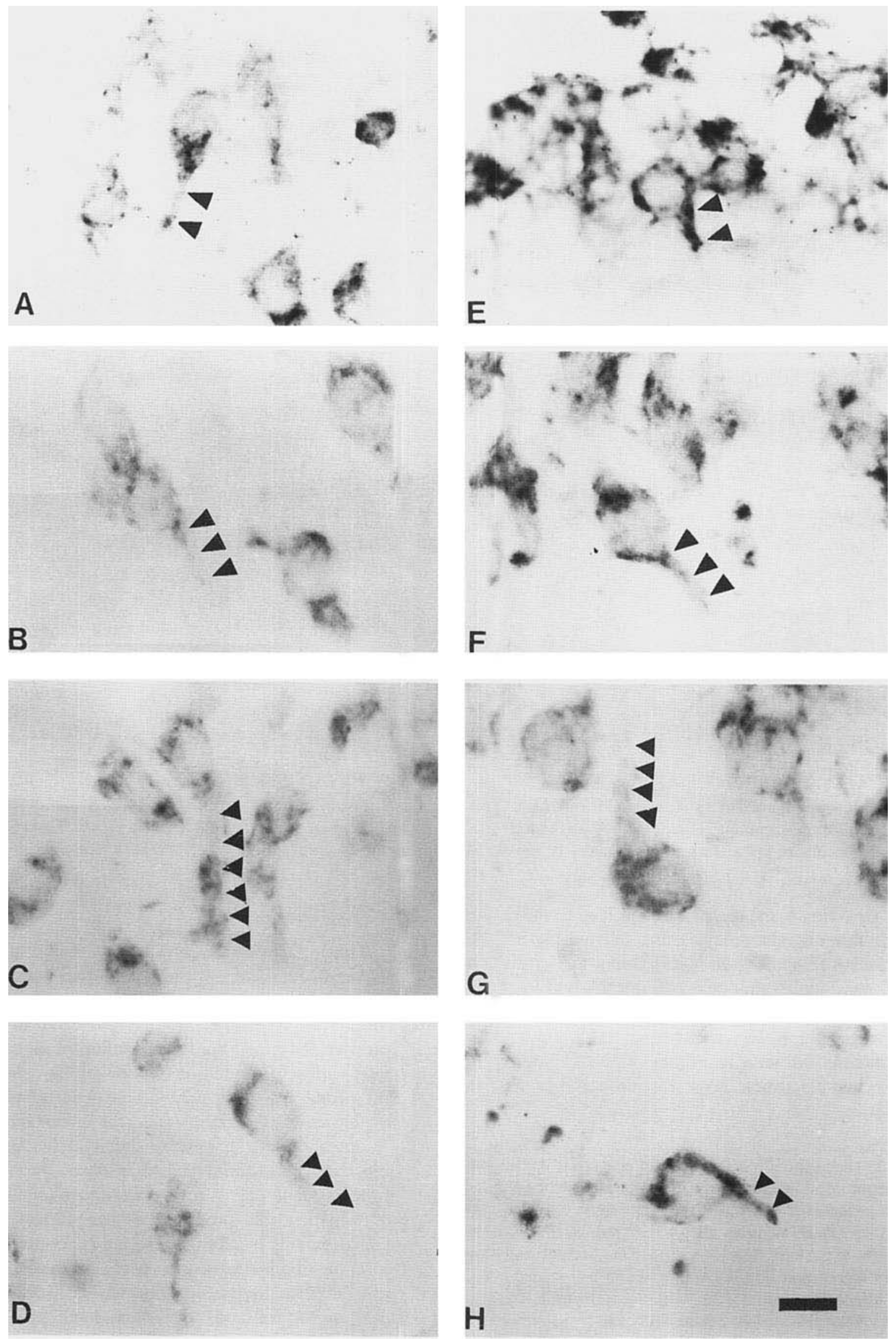

Fig. 5. (Legend appears on page 660.) 

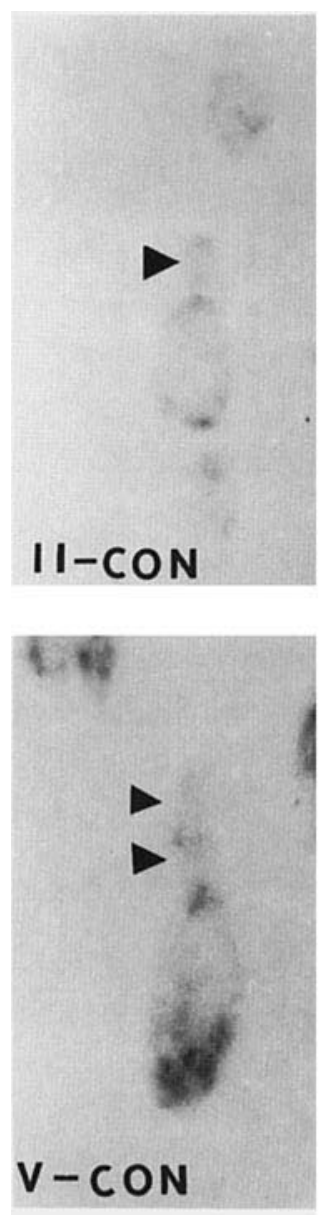
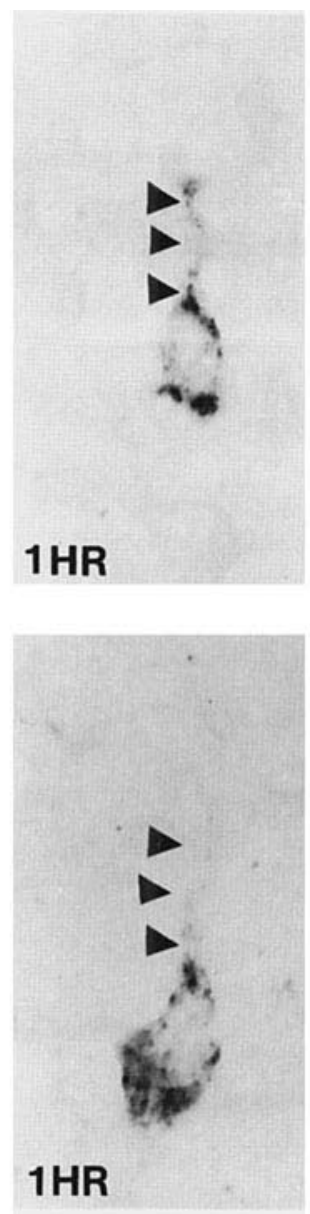
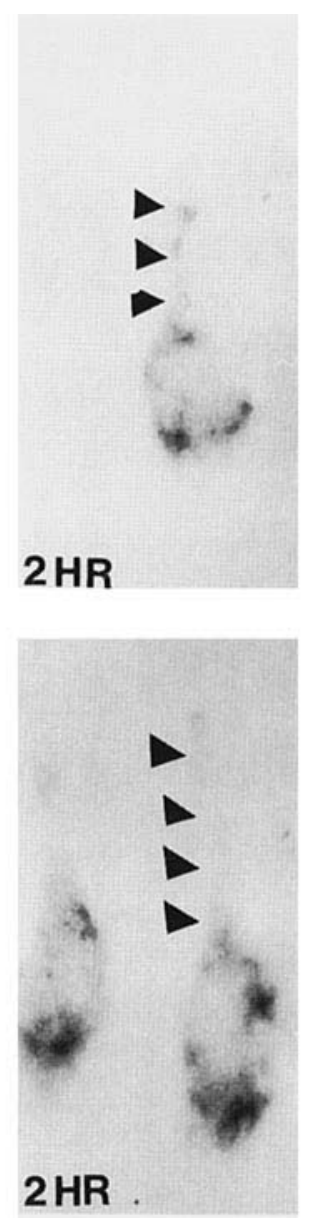
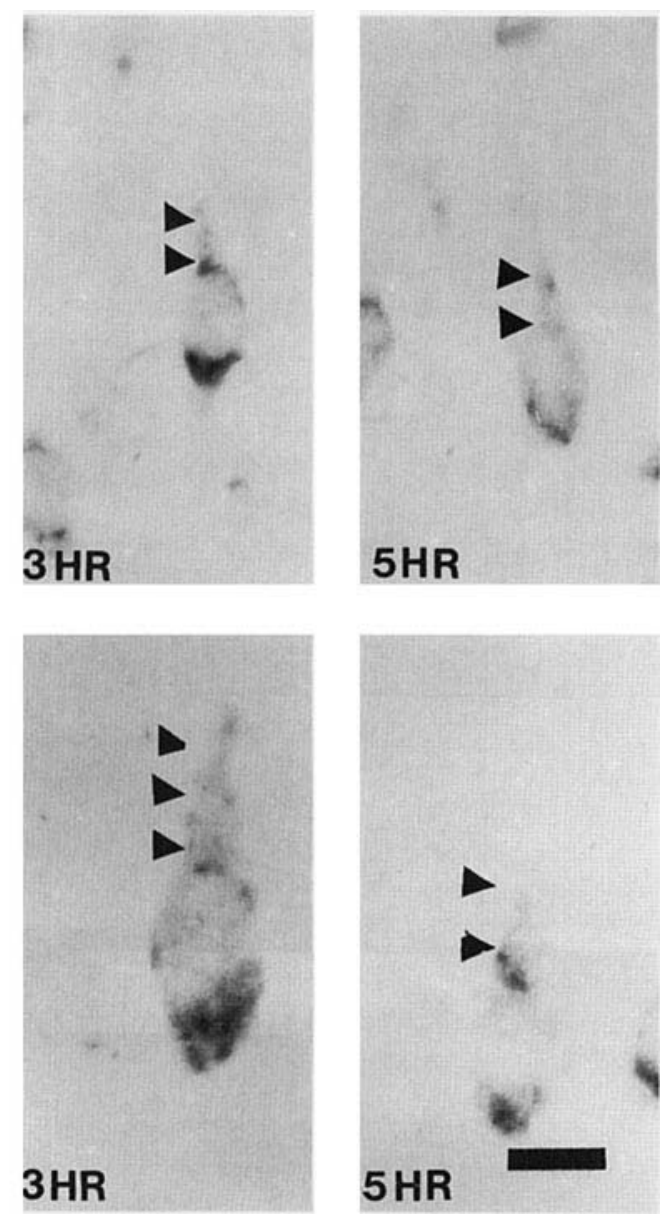

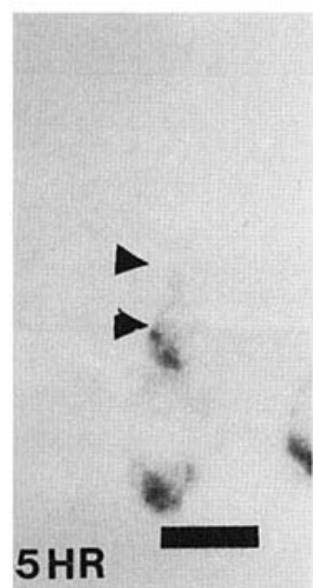

Fig. 6. Intracellular distribution of hsc $70 \mathrm{mRNA}$ in cortical neurons after hyperthermia. Hsc70 mRNA was detected in the apical dendrites of cortical neurons in layers II and V. More distal dendritic transport of hsc70 mRNA was observed after hyperthermia, particularly at 1 and 2 hours. Arrowheads indicate mRNA signal in cellular processes. Scale bar $=10.6 \mu \mathrm{m}$.
$8 \mathrm{C})$. By 5 hours, the signal was confined to the cell body of the few oligodendrocytes that showed hsp70 mRNA expression (Fig. 8D). In hippocampal and cortical neurons, basal expression of hsp70 mRNA was localized to the cell bodies (Fig. 4). After heat shock, dendritic transport of hsp70 mRNA was not observed in these neuronal populations, as seen in Figure 8E (CA3 neurons at 3 hours) and $\mathrm{F}$ (cortical layer $\mathrm{V}$ neuron at 3 hours).

Fig. 5. (See page 659.) Time course analysis of hsc70 mRNA in hippocampal neurons after hyperthermia. More distal dendritic transport of hsc70 mRNA was observed in CA4 (A-D) and CA3 (E-H) neurons after hyperthermia. This was most apparent at 3 hours (CA4, C; $\mathrm{CA} 3, \mathrm{G})$. At later time points, dendritic transport of mRNA appeared to be reduced (D, CA4 at 5 hours; $\mathrm{H}, \mathrm{CA} 3$ at 10 hours). Hyperthermic time points were 1 hour in $\mathrm{A}$ and $\mathrm{E} ; 2$ hours in $\mathrm{B}$ and $\mathrm{F} ; 3$ hours in $\mathrm{C}$ and G; 5 hours in D; 10 hours in H. Scale bar $=10.6 \mu \mathrm{m}$.

\section{DISCUSSION}

The intracellular localization of hsc70 and hsp70 mRNAs in neural cells of the rabbit brain was examined using nonradioactive in situ hybridization. Hybridization of control tissue sections with a DIG-labeled hsc70 riboprobe revealed a cell body distribution of signal. Additionally, in several neuronal populations, constitutive hsc70 mRNA was detected in apical dendritic processes. These experiments demonstrated the advantage of antibody detection of the mRNA signal in tissue sections hybridized with DIG-labeled riboprobes. Improved resolution was apparent, as it was possible to localize hsc70 mRNA in dendritic processes with a diameter of 1-2 $\mu \mathrm{m}$. Comparable resolution of signal is not possible with radioactive riboprobes (Foster et al., 1995).

In control tissue, constitutive hsc70 mRNA was detected in the cell body and apical dendrites of cortical neurons in layer II and V, CA3 and CA4 hippocampal 

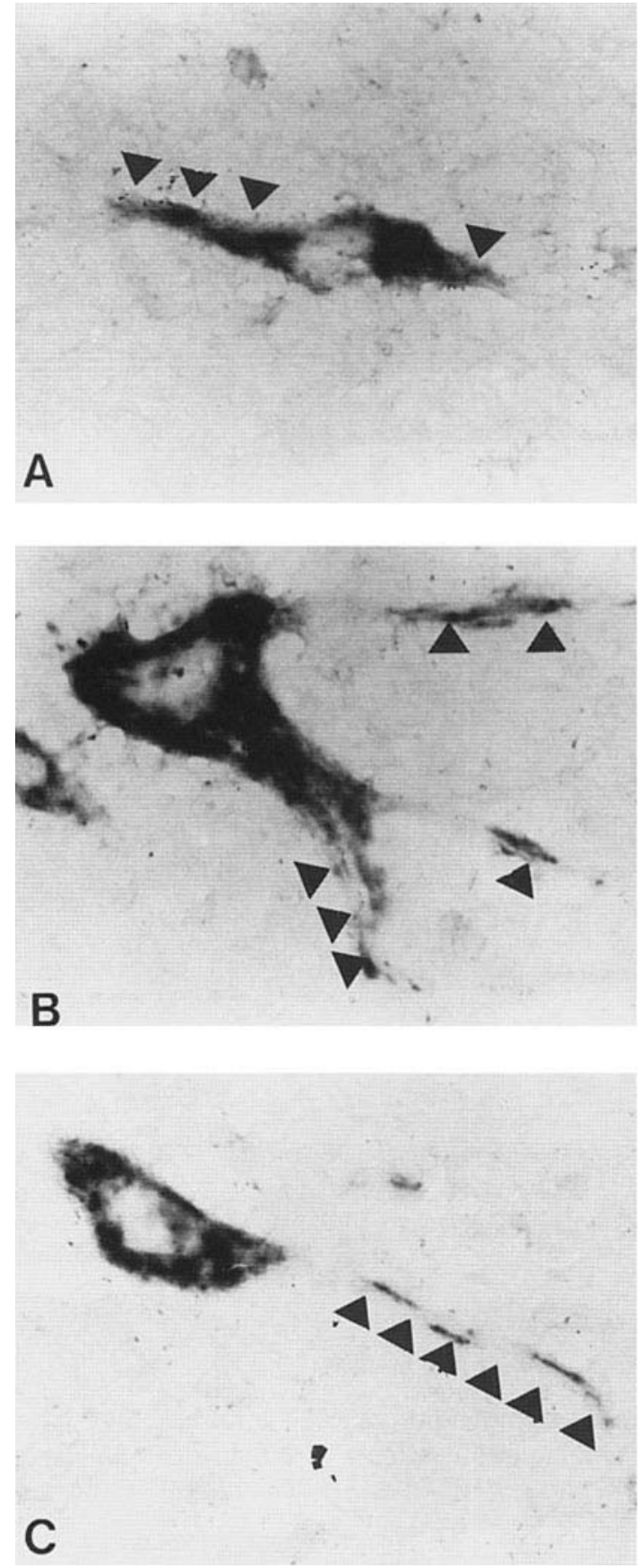

Fig. 7. Dendritic transport of hsc70 mRNA in deep cerebellar and brainstem neurons after hyperthermia. Hsc70 mRNA was apparent in dendritic processes of deep cerebellar neurons (A) and brainstem neurons (B) in 1-hour hyperthermic animals. Brainstem neurons showed more distal dendritic transport of hsc70 mRNA at 3 hours (C). D: hsc70 mRNA (black precip-

neurons, deep cerebellar neurons, and brainstem neurons. After physiologically relevant hyperthermia, more distal transport of this message was detected in these
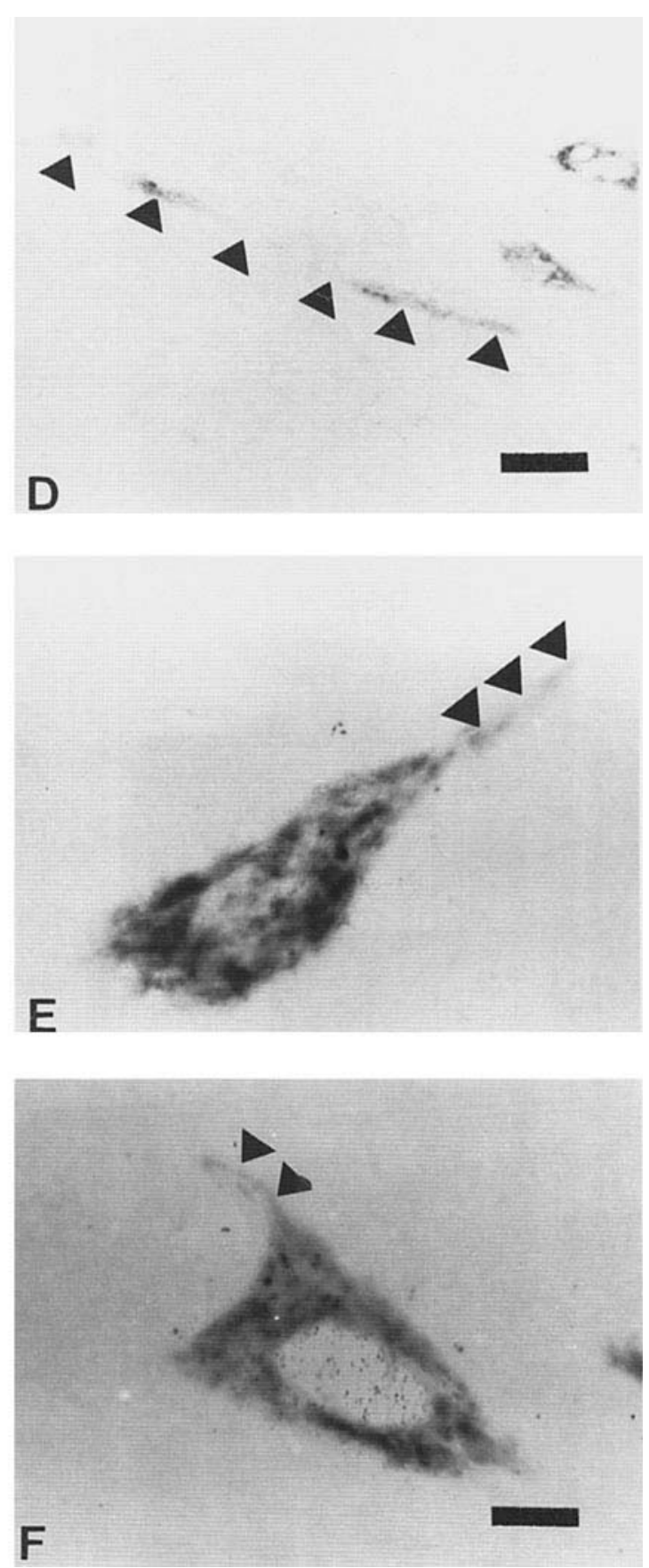

itate) was transported $175 \mu \mathrm{m}$ from the cell body of this brainstem neuron at 3 hours. At later time points, distal transport of hsc70 mRNA was reduced in brainstem neurons ( $\mathbf{E}, 5$ hours; F, 10 hours). Arrowheads indicated mRNA signal in processes. Scale bars $=10.6 \mu \mathrm{m}$ in $\mathrm{A}-\mathrm{C}, \mathrm{E}$, and $\mathrm{F} ; 37.6 \mu \mathrm{m}$ in $\mathrm{D}$.

same neuronal populations. In other neurons, such as cortical layer I, III, IV, and VI neurons, CA1 hippocampal neurons, Purkinje neurons, and basket neurons, 

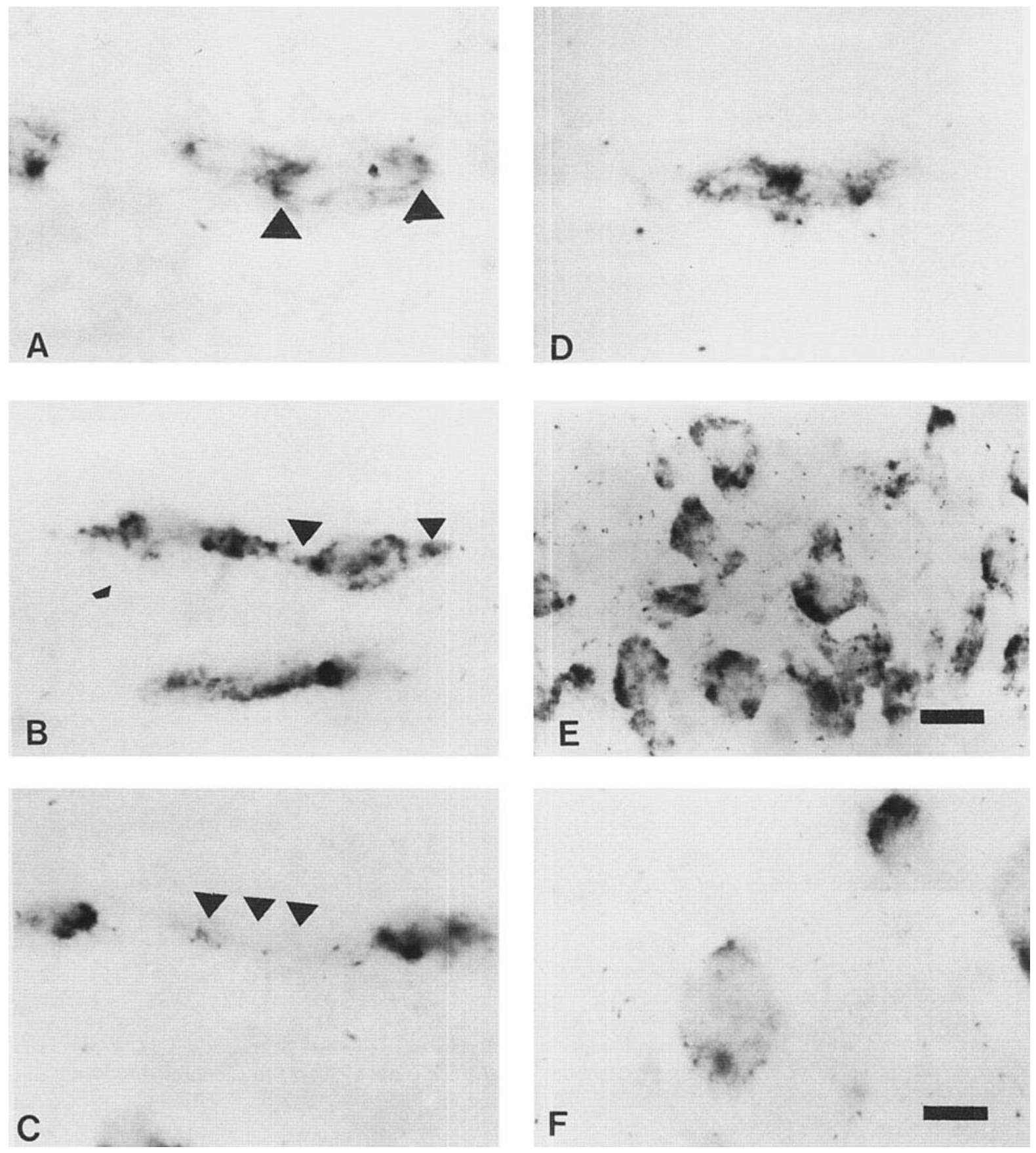

Fig. 8. Intracellular distribution of hsp $70 \mathrm{mRNA}$ in oligodendrocytes and neurons after hyperthermia. After hyperthermia, an induction of hsp70 mRNA was observed in oligodendrocytes of the corpus callosum. At 1 hour (A), hsp70 mRNA was localized to cytoplasmic cap regions of oligodendrocytes. At 2 hours (B), a more spindle-like distribution of signal was apparent, and by 3 hours, hsp70 mRNA was more distally transported in cellular processes (arrowheads, C). By 5 hours (D),

signal was confined to the cell body of the few cells that expressed hsp 70 mRNA. Expression of hsp70 mRNA in CA4 hippocampal neurons (E) and cortical neurons (N) (F) was confined to the cell body in 3-hour hyperthermic animals. Hyperthermic time points were 1 hour in $\mathrm{A} ; 2$ hours in $\mathrm{B} ; 3$ hours in C, E, and F; 5 hours in D. Scale bars $=8.2 \mu \mathrm{m}$ in A-C, D, and $F ; 10.6 \mu \mathrm{m}$ in $\mathrm{E}$. 
hsc70 mRNA was restricted to the neuronal cell body in both control and hyperthermic animals. Similarly, hsp70 mRNA in control and hyperthermic animals was also restricted to neuronal cell bodies.

Recently, there has been increased interest in intracellular localization of mRNA in neural cells (Steward et al., 1994). Early work detected polysomes at the base of dendritic spines (Steward and Levy, 1982). More recent experiments have demonstrated the presence of translational machinery at the base of dendritic spines (Torre and Steward, 1992). Pulse chase experiments with ${ }^{3} \mathrm{H}$-uridine in hippocampal neurons revealed dendritic transport of mRNA at a rate of $0.4-0.5 \mathrm{~mm} /$ day (Davis et al., 1987). In situ hybridization in developing rat brain showed dendritic localization of MAP2 mRNA in the hippocampus and cortical layers, whereas a second MAP family member, MAP5 mRNA, was found only in the cell body of developing neurons (Garner et al., 1988; Tucker et al., 1989). These observations parallel the present results on the hsp 70 multigene family. In cortical layer $\mathrm{V}$ neurons, dendritic localization of one family member, hsc70 mRNA, was observed, whereas a second family member, hsp70 mRNA, was detected only in the cell body.

The list of mRNAs that are localized to dendrites includes the $\alpha$ subunit of calcium/calmodulin-dependent protein kinase II mRNA (Burgin et al., 1990), calmodulin I mRNA (Berry and Brown, 1996), activity-regulated cytoskeleton-associated protein (Arc) mRNA (a novel cytoskeleton-associated protein enriched in dendrites) (Lyford et al., 1995), and a nontranslated RNA, BC1 (Tiedge et al., 1991). Although proteins, including GAP-43, neurofilament- 68 , and $\beta$-tubulin, are enriched in dendrites, mRNAs encoding these proteins are restricted to neuronal cell bodies (Kleiman et al., 1990). Thus, only a subset of neuronal mRNAs is a candidate for dendritic transport.

Localization of certain mRNAs to discrete intracellular domains below dendritic spines may facilitate local regulation of protein synthesis at the synapse (Steward et al., 1994). For example, Arc mRNA is distributed in dendrites, and its encoded protein has been shown to be up-regulated in an activity-dependent manner in response to synaptic activity (Lyford et al., 1995). In the case of abundant proteins, including hsc70, mRNA localization in dendrites is a cellular strategy that could regulate changes in protein levels in the microenvironment of the synapse. In response to synaptic activity, hsc70 protein levels could be increased at highly localized dendritic sites. Hsc70 mRNA located in dendrites may also provide the cell with a mechanism to increase hsc70 protein levels at synaptic sites that are distant from the cell body, in response to cellular stress, where hsc70 protein may function in repair and protection.
In addition, more distal transport of hsc70 mRNA was observed in neurons after hyperthermia. In the present experiments, it is not possible to distinguish whether this observation is the result of increased transport of mRNA or increased stability of the existing mRNA. It is possible that both increased transport and increased stabilization of mRNA may play a role in the neuronal response to hyperthermia. The reported rate of mRNA dendritic transport in hippocampal neurons in culture was $0.4-0.5 \mathrm{~mm} /$ day or $17-21 \mu \mathrm{m} / \mathrm{hr}$ (Davis et al., 1987). However, the rate of dendritic transport may increase after hyperthermia, and the transport rate of mRNA in brainstem neurons may be different than the reported rate for hippocampal neurons in culture.

A strong induction of hsp70 mRNA has been reported in oligodendrocytes in forebrain, cerebellum, and brainstem regions (Foster et al., 1995; Foster and Brown, in press). The intracellular localization of hsp70 mRNA in this glial cell type was examined by nonradioactive in situ hybridization. This analysis revealed hsp70 mRNA in cytoplasmic cap regions of oligodendrocytes at 1 hour, a spindle-like distribution of hsp70 mRNA at 2 hours, and a more distal transport into glial cell processes, up to $40 \mu \mathrm{m}$ from the cell body, at 3 hours. As discussed previously, transport of mRNA in neural processes at a rate of $0.4-0.5 \mathrm{~mm} / \mathrm{day}$ was reported in cultured hippocampal neurons (Davis et al., 1987). The transport of newly synthesized hsp70 mRNA in oligodendrocyte processes after hyperthermia is in line with that reported rate.

The mechanisms involved in targeting and transport of mRNAs to dendrites are not understood. In nonneural tissues, the $3^{\prime}$ noncoding region has been shown to contain elements that are involved in targeting of mRNAs to intracellular locations, such as bicoid (BCD) mRNA during Drosophila embryogenesis (Macdonald and Struhl, 1988), Vg1 mRNA during Xenopus embryogenesis (Mowry and Melton, 1992), and $\alpha$ - and $\beta$-actin mRNAs in fibroblasts (Kislauskis et al., 1993). To date, evidence is not available to support the presence of comparable elements in neuronal mRNAs that might play a role in dendritic transport.

Localization of mRNA to cellular processes is not unique to neurons and their dendrites. In oligodendrocytes, in situ hybridization experiments have revealed that myelin basic protein (MBP) mRNA is localized in oligodendrocyte processes (Trapp et al., 1987). A developmental study of MBP mRNA expression revealed that localization of this mRNA species in oligodendrocyte processes was dependent on the stage of development in mouse brain and was restricted to the cell body before postnatal day 10 (Landry et al., 1994). Those researchers also noted differences in intracellular distribution of several neuronal and non-neuronal mRNAs, suggesting that 
mRNA targeting into neural processes did not rely strictly on elements in the $3^{\prime}$ untranslated region but that factors including developmental stage and brain region affected mRNA transport (Landry et al., 1994). The present experiments support that idea; for example, basal expression of hsp70 mRNA was detected only in the neuronal cell body whereas hsp70 mRNA induced in oligodendrocytes showed distal transport into processes. Also, in cortical neurons, hsc70 mRNA was apparent in the apical dendrites of layer II and layer V neurons, and yet, in other cortical neurons (layers I, III, IV, and VI), hsc70 mRNA was detected only in the cell body. Similar results were obtained in hippocampal neurons and cerebellar neurons, which suggested that several factors contribute to the differential mRNA localization of these heat shock mRNAs.

Transport of mRNAs into cellular processes may rely on cytoskeletal associations (Singer, 1992). Using dual in situ/immunocytochemistry in fibroblast cells, studies have demonstrated that poly(A) mRNA was colocalized with cytoskeletal components such as actin, vimentin, and microtubules (Bassell et al., 1994a). Also, in cultured rat cortical neurons, poly(A) mRNA localized in dendrites was bound to cytoskeletal components (Bassell et al., 1994b), and specifically, MAP2 mRNA was associated with the Triton $X$ insoluble fraction of neurons, indicating its association with cytoskeletal components of the cell (Bruckenstein et al., 1990). Further work is needed to elucidate the mechanisms involved in mRNA localization and transport in neural cell types. Heat shock mRNAs are good candidates for such investigations, because the present research suggests that the two mRNAs are differentially regulated with respect to dendritic transport in neurons, and furthermore, hsc 70 mRNA was selectively transported in some neuronal populations and not in others.

Overall, the experiments discussed above show that although both heat shock messages are expressed in unstressed neurons, the intracellular localization of hsc70 and hsp70 mRNA differ. Dendritic localization of hsc70 mRNA was detected in certain unstressed neuronal populations. After hyperthermia, more distal transport of hsc70 mRNA was observed in all neurons, which showed dendritic localization of signal in the unstressed animal. The observed transport of hsc70 mRNA into the dendritic processes may allow for local control of hsc70 protein synthesis at synapses. Local regulation of hsc70 protein synthesis could occur at the base of dendritic spines in response to changes in synaptic activity in the unstressed neuron. After a cellular stress, hsc70 protein levels could be rapidly increased in neuronal processes, due to the presence of hsc 70 mRNA. Increased hsc 70 protein in regions that are remote from the cell body may be important for repair and protection. In oligodendro- cytes, hsp70 mRNA was transported into processes after hyperthermia, and that could allow local control of synthesis of this heat shock protein in glial processes.

\section{ACKNOWLEDGMENTS}

These studies were supported by grants from MRC (Canada) to I.R.B.

\section{REFERENCES}

Ashburner M, Bonner JJ (1979): The induction of gene activity in Drosophila by heat shock. Cell 17:241-254.

Bassell GJ, Powers CM, Taneja KL, Singer RH (1994a): Single mRNAs visualized by ultrastructural in situ hybridization are principally localized at actin filaments intersections in fibroblasts. J Cell Biol 126:863-876.

Bassell GJ, Singer RH, Kosik KS (1994b): Association of poly(A) mRNA with microtubules in cultured neurons. Neuron 12:571582.

Becker J, Craig EA. (1994): Heat-shock proteins as molecular chaperones. Eur J Biochem 219:11-23.

Berry F, Brown IR (1996): CaM I mRNA is localized to apical dendrites during postnatal development of neurons in the rat brain. J Neurosci Res 43:565-575.

Brown IR (1994): Induction of heat shock genes in the mammalian brain by hyperthermia and tissue injury. In RJ Mayer, IR Brown (eds): "Heat Shock Proteins in the Nervous System." London: Academic Press, pp 31-53.

Bruckenstein DA, Lein PJ, Higgins D, Fremeau RT (1990): Distinct spatial localization of specific mRNAs in cultured sympathetic neurons. Neuron 5:809-819.

Burgin KE, Washam MN, Rickling S, Westgate SA, Mobley WC, Kelly PT (1990): In situ hybridization histochemistry of $\mathrm{Ca}++/$ calmodulin-dependent protein kinase in developing rat brain. J Neurosci 10:1788-1798.

Cosgrove JW, Brown IR (1983): Heat shock protein in the mammalian brain and other organs following a physiologically relevant increase in body temperature induced by LSD. Proc Natl Acad Sci USA 80:569-573.

Craig EA (1989): Essential roles of $70 \mathrm{kDa}$ heat inducible proteins. BioEssays 11:48-52.

Davis L, Banker GA, Steward O (1987): Selective dendritic transport of RNA in hippocampal neurons in culture. Nature 330:477479.

Foster JA, Brown IR (1996): Basal expression of stress-inducible hsp 70 mRNA detected in hippocampal and cortical neurons of normal rabbit brain. Brain Res 724:73-83.

Foster JA, Brown IR (1996): Differential induction of heat shock mRNA in oligodendrocytes, microglia, and astrocytes following hyperthermia. Mol Brain Res, in press.

Foster JA, Rush SJ, Brown IR (1995): Localization of constitutive and hyperthermia-inducible heat shock mRNAs (hsc70 and hsp70) in the rabbit cerebellum and brain stem by non-radioactive in situ hybridization. J Neurosci Res 41:603-612.

Garner CC, Tucker RP, Matus A (1988): Selective localization of messenger RNA for cytoskeletal protein MAP2 in dendrites. Nature 336:674-677.

Georgopoulos C, Welch WJ (1993): Role of the major heat shock proteins as molecular chaperones. Annu Rev Cell Biol 9:601634. 
Gething M-J, Sambrook J (1992): Protein folding in the cell. Nature 355:33-45.

Hartl F-U, Hlodan R, Langer T (1994): Molecular chaperones in protein folding: The art of avoiding sticky situations. Trends Biochem Sci 19:20-25.

Kislauskis EH, Li Z, Singer RH, Taneja K (1993): Isoform-specific $3^{\prime}$-untranslated sequences sort alpha-cardiac and beta-cytoplasmic actin messenger RNAs to different cytoplasmic compartments. J Cell Biol 123:165-172.

Kleiman R, Banker G, Steward O (1990): Differential subcellular localization of particular mRNAs in hippocampal neurons in culture. Neuron 5:821-830.

Landry CF, Watson JB, Kashima T, Campagnoni AT (1994): Cellular influences on RNA sorting in neurons and glia: an in situ hybridization histochemical study. Mol Brain Res 27:1-11.

Lindquist S (1980): Varying patterns of protein synthesis in Drosophila during heat shock: Implications for regulation. Dev Biol 77:463-479.

Lindquist S (1986): The heat-shock response. Annu Rev Biochem 55:1151-1191.

Lindquist S, Craig EA (1988): The heat shock proteins. Annu Rev Genet 22:631-677.

Lyford GL, Yamagata K, Kaufmann WE, Barnes CA, Sanders LK, Copeland NG, Gilbert DJ, Jenkins NA, Lanaham AA, Worley PF (1995): Arc, a growth factor and activity-regulated gene, encodes a novel cytoskeleton-associated protein that is enriched in neuronal dendrites. Neuron 14:433-445.

Macdonald PM, Struhl G (1988): Cis-acting sequences responsible for anterior localization of bicoid mRNA in Drosophila embryos Nature 336:595-598.

Manzerra P, Brown IR (1990): Time course induction of a heat shock gene (hsp70) in the rabbit cerebellum after LSD in vivo: Involvement of drug-induced hyperthermia. Neurochem Res 15 : 53-59.

Manzerra P, Brown IR (1992a): Distribution of constitutive- and hyperthermia-inducible heat shock mRNA species (hsp70) in the Purkinje layer of the rabbit cerebellum. Neurochem Res 17: $559-564$.

Manzerra P, Brown IR (1992b): Expression of heat shock genes (hsp70) in the rabbit spinal cord: Localization of constitutive and hyperthermia-inducible mRNA species. J Neurosci Res 31:606-615.

Manzerra P, Rush SJ, Brown IR (1993): Temporal and spatial distribution of heat shock mRNA and protein (hsp70) in the rabbit cerebellum in response to hyperthermia. J Neurosci Res 36: 480-490.

Mowry KL, Melton DA (1992): Vegetal messenger RNA localization directed at a 340-nt RNA sequence element in Xenopus oocytes. Science 255:991-994.

Nover L, Scharf K (1991): Heat shock proteins. In L. Nover (ed): "Heat shock response." Boca Raton, Florida: CRC Press Inc., pp 41-150.
Pelham $H$ (1988): Heat shock proteins: Coming in from the cold. Nature 332:776-777.

Pelham HRB (1986): Speculations of the functions of the major heat shock and glucose-regulated proteins. Cell 46:959-961.

Peterson SL, McCrone S (1994): Characterization of the receptor complement of individual neurons using dual-label in situ hybridization histochemistry. In JH Eberwine, KL Valentino, JD Barchas (eds): "In Situ Hybridization in Neurobiology." New York: Oxford University Press, pp 78-95.

Schlesinger MJ, Ashburner M, Tissieres A (1982): "Heat Shock: From Bacteria to Mar." Cold Spring Harbor, NY: Cold Spring Harbor Press.

Singer RH (1992): The cytoskeleton and mRNA localization. Curr Opin Cell Biol 4:15-19.

Sprang GK, Brown, IR (1987): Selective induction of a heat shock gene in fibre tracts and cerebellar neurons of the rabbit brain detected by in situ hybridization. Mol Brain Res 3:89-93.

Steward O, Levy WB (1982): Preferential localization of polyribosomes under the base of dendritic spines in granule cells of the dentate gyrus. J Neurosci 2:284-291.

Steward O, Kleiman R, Banker G (1994): Sorting and intracellular transport of RNA in neurons: Regulation of gene expression at synaptic sites. In PJ Harrison (eds): "Regulation of Gene Expression and Brain Function." Berlin: Springer-Verlag, pp 1729.

Tiedge H, Fremeau RT, Weinstock PH, Arancio O, Broxius J (1991): Dendritic localization of BC1 RNA. Proc Natl Acad Sci USA 88:2093-2097.

Torre ER, Steward O (1992): Demonstration of local protein synthesis within dendrites using a new cell system that permits the isolation of living axons and dendrites from their cell bodies. $J$ Neurosci 12:762-772.

Trapp BD, Moench T, Pulley M, Barbosa E, Tennekoon G, Griffin J (1987): Spatial segregation of mRNA encoding myelin-specific proteins. Proc Natl Acad Sci USA 84:7773-7777.

Tucker RP, Garner CC, Matus A (1989): In situ localization of microtubule-associated protein mRNA in the developing and adult rat brain. Neuron 2:1245-1256.

Watowich SS, Morimoto RI (1988): Complex regulation of heat shock- and glucose-responsive genes in human cells. Mol Cell Biol 8:393-405.

Welch WJ (1992): Mammalian stress response: Cell physiology, structure/function of stress proteins, and implications for medicine and disease. Physiol Rev 72:1063-1081.

Welch WJ (1993): Heat shock protein functioning as molecular chaperones: Their roles in normal and stressed cells. Philos Trans R Soc Lond [Biol] 339:327-333.

Wu B, Hunt C, Morimoto RI (1985): Structure and expression of the human gene encoding major heat shock protein hsp70. Mol Cell Biol 5:330-341. 